\title{
Hand Hoeing Weeding Frequency on Growth of Tobacco under the Ecological Conditions of Shewa Robit and Bilatte Tobacco Farms, Ethiopia
}

\author{
Daniel Abebe $^{1 *}$, Mekonnen Tadesse ${ }^{1}$, Mesfin Shiferaw ${ }^{1}$ \\ ${ }^{1}$ National Tobacco Enterprise (Ethiopia) S.C, Addis Ababa, Ethiopia.
}

\begin{abstract}
How to cite this paper: D. Abebe, Me. Tadesse, M. Shiferaw. (2020) Hand Hoeing Weeding Frequency on Growth of Tobacco under the Ecological Conditions of Shewa Robit and Bilatte Tobacco Farms, Ethiopia. International Journal of the Science of Food and Agriculture, 4(1), 97-100

DOI: $10.26855 /$ ijfsa.2020.03.014
\end{abstract}

Received: February 25, 2019

Accepted: March 10, 2020

Published: March 24, 2020

*Corresponding author: Daniel Abebe, National Tobacco Enterprise (Ethiopia) S.C, Addis Ababa, Ethiopia.

Email: danjitu79@yahoo.com

\begin{abstract}
An experiment was conducted at Bilatte and Shewa Robit tobacco farms in Ethiopia during 2012/13 and 2013/14 dry and wet cropping season respectively, with objective of evaluating the effect of frequency of hand hoeing weeding on growth characteristics and yield of flue-cured tobacco. The treatments include: weedy check, weed free check, weeding at 15 and 45 days after transplanting (DAT), weeding at 15,30, 45 and 60 DAT and weeding at 30, 45, 60, 90 and 120 days DAT. The experimental result revealed that frequency of different hand hoeing levels has an effect on yield and growth characteristics of tobacco. Weeding of tobacco four or five times, especially at 15, 30, 45, 60 and 90 DAT gave relatively better yield and found recommendable under Bilatte and Shewa Robit conditions.
\end{abstract}

Keywords

Characteristics, Ethiopia, Growth, Tobacco, Weeding, Vegetative

\section{Introduction}

Weeds compete with cultivated food crop for limited resources such as water, nutrients and light [1]. Weeds infested also encourage disease problem, serve as alternate host for deleterious insect and disease, slow down harvesting operation, increase the cost of production, and causing noticeable crop damage that leads to yields reduction and poor quality crops [2]. National Tobacco Enterprise (Ethiopia) S.C by own state-owned farms and small scale out-grower farmers weeded their tobacco field three - four times depend upon the availability of labour and the nature of weed infestation. However, hand hoe system is time-consuming, back-breaking and expensive too especially where labour is scarce than other methods, when conducted on large areas with heavy infestation of weeds [3]. In the hand hoe system, weeding alone accounts for 40-54\% of the total labor input in farming in Ghana, Nigeria, Upper Volta, Sierra Leone, Malawi, Zambia, Ethiopia and Tanzania, requiring 300-400 man- hours per hectare [1]. In most cases, due to limitations on family labour, tobacco growing farmers is not well planned with respect to tobacco phenology and critical period of weeding competition of tobacco.

The critical weed free period or the minimum length of time required for the crop to be maintained weed free period before yield losses caused by late emerging weed is no longer concern [4]. Rather, weeding is done at accidental time and when labor is available. Therefore, weed control is an important management practice for tobacco production that should be carried out to ensure optimum green leaf yield.

Despite its economic importance tobacco in the past, no research has been carried out on frequencies manage- 
ment weeds of tobacco technology. Therefore, the objective of this experiment was to determine the effect weeding frequencies on tobacco performance and to estimate the optimum timing for weed control under growing condition of Bilatte and Shewa Robit tobacco farms, Ethiopia.

\section{Materials and Methods}

\subsection{Description of the study areas}

The experiment was performed at Bilatte and Shewa Robit tobacco farms 2012 -13 and 2013-14 in short and main rainy seasons respectively. Bilatte is located in southern Ethiopia, in Welayita zone and $80 \mathrm{~km}$ from the capital city of Southern Nations Nationalities and Peoples Regional State (SNNPR) Hawassa. It is at about $355 \mathrm{Km}$ south of Addis Ababa. Its geographical is situated between latitude $6^{\circ} 48^{\prime} 30^{\prime \prime}$ to $6^{\circ} 49^{\prime} 48^{\prime \prime} \mathrm{N}$ and between longitude $38^{\circ} 03^{\prime}$ $05^{\prime \prime}$ to $38^{\circ} 06^{\prime} 02^{\prime \prime}$ E. Shewa Robit tobacco farm is located in the Northern Shewa zone of the Amhara Regional State, Ethiopia. Its geographical extent ranges from $10^{\circ} 39^{\circ} 54^{\circ}$ " $\mathrm{N}$ longitude and $39^{\circ} 54^{\circ}$ " E latitude and at an elevation of 1280 meters above mean sea level. It is at about $215 \mathrm{~km}$ from Addis Ababa, Ethiopia. Both leaf development farms are located in Eastern Africa Rift valley. Therefore, the two areas have more or less similar weather conditions.

\subsection{Data collection and analysis}

Data were collected for samples of five plants were taken from 3 rows of each experimental unit to measure the following growth parameters:- stem diameter $(\mathrm{cm})$, number of leaves/ plant, leaf size $(\mathrm{cm})$ and green leaf yield per plant. Weed count data (no. m-2) were collected in all plots for both locations before harvesting tobacco. Weed species compositions in two locations were assessed by throwing a $1 \mathrm{~m} \times 1 \mathrm{~m}$ metal quadrant randomly 3 times per plot data in order to obtain a reasonably good estimate of weeds. All weeds within quadrant were uprooted and separated into broad and grass leaves counted. Data were analyzed statistically using analysis of variance was using SAS statistical package [5].

\subsection{Experimental treatments, design and procedure}

A tobacco crop (Nicotiana tabacum L.) variety K-110 was established in the experimental field. The hand hoeing weeding treatments consisted of five levels:- no weeding, free check, 2 weeding ( 15 and 45 days after transplanting ), 4 weeding $(15,30,45$ and 60 days after transplanting) and 5 weeding $(15,30,45,60$ and 90 days after transplanting), designated as W0, WF, W2, W4 and W5 respectively. The experiment was laid out in a Randomized Complete Block Design with three replications. The distances between plants was $0.6 \mathrm{~m}$ and between rows $1.2 \mathrm{~m}$ with plot size $2.4 \mathrm{~m} \times 2.4 \mathrm{~m}=5.76 \mathrm{~m} 2$ ( 3 rows, 5 plant/row). Planting dates at Bilatte were on 23rd December in 2012 and 18th April in 2013, and for Robi location 27th May in 2013 and 15th January in 2014 for short and main rainy season respectively. The land was plowed with tractor. Fertilizer was applied at the rate of $100 \mathrm{~kg}$ ha- 1 urea and $\mathrm{P} 2 \mathrm{O} 5$ for both locations.

\section{Results and discussion}

\subsection{Plant height}

Plant height showed significance difference $(\mathrm{p}<0.05)$ in response to the use of different hand hoeing frequency in both locations. The highest plant height at Bilatte and Robi in weed free check was recorded 1.58 and $1.35 \mathrm{~cm}$. However, 4th and 5th hand hoeing weeding gave equivalent and the highest plant height. Mean plant height at Bilatte and Robi $(1.55,1.55)$ and $(1.23,1.24)$ has recorded respectively compared to weedy check. Weedy Plot gave lower mean plant height per plant 0.57 and $1.00 \mathrm{~cm}$ respectively. The presence of significant variation among plant height due to weeding frequency results agreed evidence were reported in different crop by [6-9], they found that, increasing weeding times increased plant height, due to efficient weed control.

\subsection{Leaves of size}

Size of Leaves e showed significance difference $(\mathrm{p}<0.05)$ in response to the use different hand hoeing frequency. The highest leaves size at Bilatte $(5144.5 \mathrm{~cm} 2)$ and Robi $(2322.5 \mathrm{~cm} 2)$ were recorded in weedy free check. The weedy check gave lower mean size of leaves 490 and $887 \mathrm{~cm} 2$ recorded respectively. Data indicated that leaf sizes at Robi and Bilatte in weed free treatments were recorded high compared with un-weeded plot. This might be related to that increased weeding frequencies increased leaf size due to better control of weeds. This show, that weeding 
played important role in leaves production via its role in vegetative growth and this might be increased availability of resources due to weeding like nutrients, soil moisture and light paved way for higher leaf size per plant.

\subsection{Stem diameter and number of leaves}

Stem diameter and number of leaves per plant showed significance difference $(p<0.05)$ in response to the use different hand hoeing frequency. The highest number of leaves $(25.68,27.00)$ and stem diameter $(4.39,5.0 \mathrm{~cm})$ in Bilatte and Robi respectively recorded on weed free check. However, hand hoeing frequency Five times gave equivalent and the highest leave number at both locations and stem diameter at Robi recorded comparable result to weed free check and 4 times hand hoeing. The weedy check occupied the bottom position with $(12,11)$ leaves number per plant and $(1.42,1.20 \mathrm{~cm})$ stem diameter per plant in the rank order of treatments respectively.

\subsection{Green leaves yield per plant}

The combined analysis for two seasons indicated that effect of hand hoeing frequency on green leaves yield per plant dependent on location variations. In Bilatte and Robi, weeding four and five times produced $(58,65.28 \%)$ and $(72.43,78.5 \%)$ more green leaves yield than un-weeded respectively. This indicated that uncontrolled weeds in both locations sever yield reduced when allowed tobacco crop compete from transplanting to field through harvesting. Therefore, tobacco production cannot achieve without adequate attention on to the alleviation of weed infestation.

\subsection{Weed species composition:}

A total of 6 major of weeds were found at Bilatte tobacco farm experimental site. Four were grass species and two were sedges. Generally, the most population density (number of weed) weed species were Cynodon dactylon, Digitaria scalarum, Digitaria abyssinica and Sorghum halepense were the most important grass weeds. Cyperus esculentus and Cyperus rotundus were from sedge. While at Robi, the maximum abundance weeds species in area were Partenium hysterophorusl, followed by Cyperus spp 10.2 and Orobanche 6\%. Weed succession and distribution pattern at Bilatte and Robi in agreement with finding of [10] and [11] the composition of the weed flora may differ depending on location.

\section{Conclusion}

Application of different hand hoeing weeding frequency had an effect on green leaves yield and yield components of tobacco. The highest green leaves yield recorded in weed free check plots followed by hand hoeing at 15, 30, 45 and 60 and 15,30,45,60 and 90 DAT are effective to control weeds, promote rapid tobacco growth and improved vegetative growth of tobacco in study areas. Hoe weeding should be started early at 15 days after transplanting because the crop never recovers fully when weeding is late. Late emerged weeds were observed at the time when the crop plants had established sufficient canopy to suppress weeds. In general, experimental result revealed that frequency of either four or five times are recommended for both locations. This information, however, is based on two season's data. Further work is required to confirm these findings, and more fundamental research should be done.

\section{References}

[1] Akobundu, I.O. (1987) Weed Science in the Tropics. John Wiley and Sons, Chicester, UK.

[2] Holm, I.G., Plucknett, D.L., Pancho, J.V., and Herberger, J.P. (1997) The world worst weeds. Distribution and biology, Honolulu University press of Hawi, 609pp.

[3] Ross, M.A., and Lembi,C.A. (1985) Applied weed science. MacMillan publishing company, New York, USA.

[4] Abbaspour, M., and Moghaddam, P.R. (2004) The critical period of weed control of corn in Mashhad region in Iran. Iran Journal of Agricultural Research, 2: 182-195.

[5] SAS (2000) The SAS system for windows. Release 8.0. SAS Institute Inc., Cary, NC, USA.

[6] Joshi, K. R. (2004) Effect of time of weeding and levels of N and P2 O5 Fertilizers on the grain yield of maize. Nepal Journal of Agricultural Research, 5: 69-70.

[7] Mubarak, H.A. (2004) Studies on weed management in irrigated groundnuts (Arachis hypogaea L) in Sudan. Ph.D. Dissertation, Faculty of Agricultural Sciences, University of Gezira, Wad Medani, Sudan.

[8] Bedry, K.A (2007) Effect of weeding regimes on fababean (Vicia faba L.) yield in the Northern State of Sudan. Khartoum. Agric Sci Univ J, 15: 220-231 
[9] El Naim, A.M., El day, E.M., and Ahmed, A.A. (2010) Effect of plant density on the performance of some sesame (Sesamum indicum L) cultivars under Rainfed. Research Journal of Agricultural and Biological Science, 6(4), 498-504.

[10] Begum, M.A.S., Jursim, M., Azami, M., Syed Omar, S.R., and Rajan, A. (2008) Weed flora of different fram block in block of muda rice in granary in penisular Malaysia. Journal of Biological Science, 19: 33-43.

[11] Uddin, M.K., Juraimi, A.S., Ismail, M.R., and Brosnan, J.T. (2010) Characterizing weed populations in different turf grass sites throughout the klang valley of western peninsular Malaysia. Weed Technology, 24:173-181.

[12] Akobundu, I.O. (1980) Advances in live mulch crop production in the tropics. Proc. Western. Society of Weed Science, $37: 51$ -57 . 